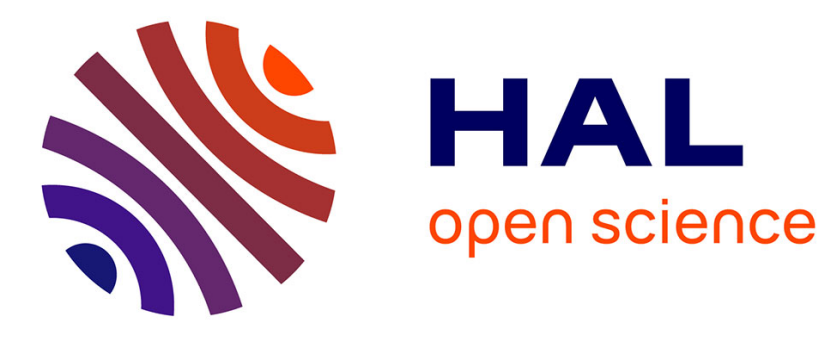

\title{
Lease Contract in Usage Based Remanufactured Equipment Service System
}

\author{
H. Husniah, U. S. Pasaribu, B. P. Iskandar
}

\section{To cite this version:}

H. Husniah, U. S. Pasaribu, B. P. Iskandar. Lease Contract in Usage Based Remanufactured Equipment Service System. IFIP International Conference on Advances in Production Management Systems (APMS), Aug 2018, Seoul, South Korea. pp.198-205, 10.1007/978-3-319-99707-0_25 . hal-02177842

\section{HAL Id: hal-02177842 \\ https://hal.inria.fr/hal-02177842}

Submitted on 9 Jul 2019

HAL is a multi-disciplinary open access archive for the deposit and dissemination of scientific research documents, whether they are published or not. The documents may come from teaching and research institutions in France or abroad, or from public or private research centers.
L'archive ouverte pluridisciplinaire HAL, est destinée au dépôt et à la diffusion de documents scientifiques de niveau recherche, publiés ou non, émanant des établissements d'enseignement et de recherche français ou étrangers, des laboratoires publics ou privés. 


\title{
Lease Contract in Usage Based
}

\section{Remanufactured Equipment Service System}

\author{
H. Husniah ${ }^{10000-1111-2222-3333]}$, U. S. Pasaribu ${ }^{2[1111-2222-3333-4444]}$ \\ and B.P. Iskandar ${ }^{3[2222-3333-4444-5555]}$ \\ ${ }^{1}$ Langlangbuana University, Bandung, Indonesia \\ ${ }^{2,3}$ Bandung Institute of Technology, Bandung, Indonesia \\ hennie.husniah@gmail.com
}

\begin{abstract}
In this paper we study a usage based lease contract for remanufactured equipment as an implementation of product service system. Under this lease contract, the equipment is leased for a period of $\Gamma$ with a maximum usage, $U$. If the usage of the equipment exceeds $U$ at time $\Gamma$, then lessee will be charged some additional cost. Otherwise there will be no additional cost. The price of the lease contract for the remanufactured equipment is much cheaper than that of a new one. As a result, the lease contract for the remanufactured equipment would be a more attractive option to the lessee. The decision problem for the lessee is to select the best option suitable to its requirement, and the decision problem for the lessor is find the optimal maintenance policy and the price for each length of periods offered. We provide numerical examples for illustrating the optimal decisions for the lessee, and the lessor, which maximizes the expected profit for each party.
\end{abstract}

Keywords: Remanufactured, lease, usage based service system, preventive maintenance, game theory.

\section{Introduction}

In recent global economy, a manufacturing company cannot just provide products alone to the customers, in order to remain competitive, but it needs to offer solutions for their businesses. An innovative way to achieve this is to offer a package of product and services called as a product-service system (PSS). [1] defines PSS as "an integrated product and service offering that delivers value in use". As a result, under PSS, there is a significant shift from a "traditional" product oriented model which provides products alone (or selling products) to a "service oriented" model (e.g. selling either product usage or performance) that will give the opportunity for the manufacturing company to gain competitive advantage [2)]. This shift also contributes to reducing associated environmental impacts (i.e. refurbishment, remanufacturing and recycling of durable products, which save more energy and reduce waste through the product's life) and the volume of goods in the economy to the sufficiency strategies and establish long-term relations with customers. The others effect of the PSS are reducing 
lifecycle impacts of products and services through product servicing, remanufacturing and recycling [3]. Research of lease contracts in PSS have been studied by many researchers (See [4], [5],[6], [7]). Since leasing equipment (rather than purchase it) becomes a common practice in company that functioning equipment as generating revenue. It also has many positive points i.e saving on initial investment, flexibility on equipment upgrading, and cost reduction in maintenance and inventory [8]. Moreover study lease contract (LC) that involves both lessee and lessor has been attracted by many researchers. A comprehensive review of LC from the lessor's or lessee's perspective can be found in [9]. For the case where the study is done from the lessor and lessee point of views then a game theory formulation is needed to modelling the decision problems (See [10]).

The LC for the new lease item, can be found in [8], [11] to name a few, whilst [12], [13] examined the lease contract for used items. Finally, [14] considered lease options which include a remanufactured equipment. When the equipment is used intensively (or with high usage) per unit of time, the usage experienced affects significantly the deterioration of the equipment. This indicates the need to consider age and usage in modelling the failure and also defining the lease contract which involves two parameters -i.e. age and usage limits (called a two dimensional lease contract). We are aware only the works by [15] and [16] belong to this group. In [15] the period of the contract is always the same with a maximum usage rate whilst [16] consider a two dimensional lease contract for maximum age or usage.

In this paper, we study a usage based lease contract for remanufactured equipment as an implementation of product service system. We consider a multi-period LC in which each period has a time limit but no usage limit. However, if the usage exceeds the maximum usage allowed in the contract, then the lessee has to pay some additional cost. In general, Original Equipment Manufacturer or OEM (as a lessor) offers not only a LC for a brand new equipment but also a LC for a remanufactured one. As the price of the LC for the remanufactured equipment is much lower than the price of a new one, and hence it would be a more attractive option to the companies. This paper deals with a multi period lease contract for a remanufactured equipment (such as dump trucks) in which the price scheme of LC gives some incentive for the lessee when the equipment is leased for more than one periods.

The paper is organised as follows. In section 2 we give model formulation for the two dimensional lease contract studied. Sections 3 and 4 deal with model analysis and the optimal decisions for the lessor and the lessee. In section 5 , we provide with a numerical example. Finally, we conclude with topics for further research in Section 6.

\section{Model Formulation}

In this section, we first define a new LC, describe failure model, formulate a preventive maintenance policy and its effect on reliability, and then obtain the expected profit for a lessor and a lessee.

$\begin{array}{llll}\text { Notations: } & \text { :Lease coverage region } & P & \text { :Lease contract price } \\ \Omega=[0, \Gamma) \times[0, \infty) & \text { :Number of PM during lease con- } & C_{b} & \text { :Annual cost } \\ N & \text { tract } & \end{array}$




\begin{tabular}{|c|c|c|c|}
\hline$T_{r}$ & $\begin{array}{l}\text { :The time to the first failure of the } \\
\text { remanufactured equipment }\end{array}$ & $C_{p}$ & $\begin{array}{l}\text { :Preventive } \\
\text { nance cost }\end{array}$ \\
\hline$y$ & :Usage rate & $C_{r}$ & :Average repair cost \\
\hline$F\left(t, \alpha_{r}\right) ; f\left(t, \alpha_{r}\right)$ & $\begin{array}{l}\text { :Distribution function and density } \\
\text { function for } T_{r}\end{array}$ & $\delta_{y}$ & $\begin{array}{l}\text { :Preventive } \\
\text { nance level }\end{array}$ \\
\hline$\lambda\left(t, \alpha_{r}\right), \Lambda\left(t, \alpha_{r}\right)$ & $\begin{array}{l}\text { :Hazard function and cumulative } \\
\text { hazard function }\end{array}$ & $U_{y}$ & $\begin{array}{l}: \text { Total usage } \\
{[0, m \Gamma)}\end{array}$ \\
\hline$E\left[\pi_{y}\right] ; E\left[\phi_{y}\right]$ & $\begin{array}{l}\text { :Expected profit for a lessor, and for } \\
\text { a lessee }\end{array}$ & $m \Gamma$ & $\begin{array}{l}\text { :Lease contract periods, } \\
\Gamma>0 \\
m=1,2, \ldots\end{array}$ \\
\hline$J^{1}\left(K, \delta_{y}\right), J^{2}\left(K, \delta_{y}\right)$ & $\begin{array}{l}\text { :Expected prev } \\
\text { and minimal re }\end{array}$ & & \\
\hline
\end{tabular}

\subsection{Multi-Period Lease Contract}

A lessee will lease the equipment for one or more periods, and use with a constant usage rate over the LC periods. A different lessee may have a different usage rate. A LC studied for a remanufactured equipment for period of $m \Gamma(\Gamma>0$ and $m=1,2, \ldots)$ with a maximum usage $\left(U_{\max }\right)$ (e.g. km travelled/ time period or machine-hours / time period). For a given lessee (or usage rate $y$ ), if the total usage at the end of a lease period, $U_{y}$ exceeds $U_{\max }$ (See Fig.1), then the lessee (or customer) will be charged an additional cost which is proportional to $\varphi=\operatorname{Max}\left\{0, U_{y}-U_{\max }\right\}=\operatorname{Max}\left\{0, y \Gamma-U_{\max }\right\}$ for one period. This additional cost is viewed as a compensation to the lessor as larger usage rate $\left(U_{y}>U_{\max }\right)$ results in more failures under LC and hence higher maintenance cost.

\subsection{Modelling Failure}

In general, most products at the end of the first life or end-of-use have a low reliability (or their reliability is below the threshold value of reliability $R^{*}$ ). Remanufacturing involves disassembly, cleaning, and refurbishment or replacement of parts to improve the reliability of the equipment to a like-new one or it improve the reliability of the product to at least the same level of the threshold reliability. Let $T_{r}$ be the time of the first failure the remanufactured product. $F(t)$ is the distribution function for $T_{r}$. If $F(t)$ is given by Weibull distribution function with $F\left(t, \alpha_{r}\right)=1-e^{-\left(t / \alpha_{r}\right)^{\beta}}$, then the reliability of the remanufactured product is $R\left(t, \alpha_{r}\right)=1-F\left(t, \alpha_{r}\right)=e^{-\left(t / \alpha_{r}\right)^{\beta}}$. As $R\left(t, \alpha_{r}\right) \geq R^{*}$, then we have $\alpha_{r} \geq t /\left\{\left(\sqrt[\beta]{-\ln R^{*}}\right\}\right.$.

We model failure of the remanufactured product as follows. It is considered that failure is not only influenced by age but also usage. Let $Y$ be the constant usage rate for a given customer (e.g. $\mathrm{y}=120 \mathrm{~km} /$ day for a dump truck). For a given customer (or usage rate, $y$ ), let $r_{y}(t)$ be the conditional hazard function which is a non-decreasing 
function of $\mathrm{t}$ (the age of the truck) and $\mathrm{y}$. An accelerated failure time (AFT) model is proposed to model the effect of age and usage rate on degradation of the truck. In AFT model the distribution function for $T_{y}$ is given by $F\left(t, \alpha_{y}\right)$, with a scale parameter given by $\alpha_{y}=\left(y_{0} / y\right)^{\rho} \alpha_{r}$ where $y_{0}$ is a nominal usage rate, $\alpha_{r}$ is the scale parameter when the truck is used in a normal mode. If the lessee uses the equipment with the usage rate exceeding the normal value, $y>y_{0}$, then $\alpha_{y}>\alpha_{r}$ or the equipment will deteriorate faster, otherwise when $y<y_{0}$ then it goes slower. Let $T_{y}$ be the time to first failure of the remanufactured product for a given lessee. The distribution function for $T_{y}$ is given by $F_{y}(t)$. Let $N_{y}(t)$ be the number of failures in $(0, t]$ for a given $y$. If all failures under the LC are minimally repaired and repair times are very small relative to the mean time between failures, then $N_{y}(t)$ is a non-homogeneous Poisson process with intensity function $r_{y}(t)$. The cumulative hazard functions associated with $r_{y}(t)$ is given by $R_{y}(t)=\int_{0}^{t} r_{y}(x) d x$.

\subsection{Modelling The Preventive Maintenance Effect}

For a given customer with $Y=y, \mathrm{PM}$ is done periodically at $k \tau_{y}, k=1,2, \ldots$ where $k$ is an integer value, and hence we have $\mathrm{k}$ disjoint intervals $-\left[0, \tau_{y}\right), \ldots$, $\left[k \tau_{y},(k+1) \tau_{y}=\Gamma\right)$. As in [16] and [17], we model the impact of PM through the reduction in the intensity function -i.e. the reduction is $\delta_{y j}$ after PM at $t_{j}, j \geq 1$, and $\delta_{y j}=\delta_{y}$. As any failure occurring between PM is minimally repaired, then the expected total number of minimal repairs over $\left[0, \Gamma_{0}\right)$ or $\left(\left[t_{j-1}, t_{j}\right), 1 \leq j \leq k\right)$ is given by $N=\sum_{j=1}^{k} \int_{t_{j-1}}^{t_{j}} r_{j-1}\left(t^{\prime}\right) d t^{\prime}$.

\section{Analysis}

We carry out the analysis to obtain the expected profit for the lessor, and the lessee.

\subsection{Lessor's Expected Profit}

The lessor's expected total cost consists of preventive maintenance cost and corrective maintenance cost. If $J^{1}\left(k_{y}, \delta_{y}\right)$ and $J^{2}\left(k_{y}, \delta_{y}\right)$ are the expected preventive maintenance cost and the expected total repair cost over the LC period $(0, m \Gamma], m=1,2, \ldots$ for a given usage rate $y$, respectively, then the expected total cost the lessor for $\mathrm{m}$ period $\mathrm{LC}, \Psi\left[k_{y}, \delta_{y}\right]$ is given by 


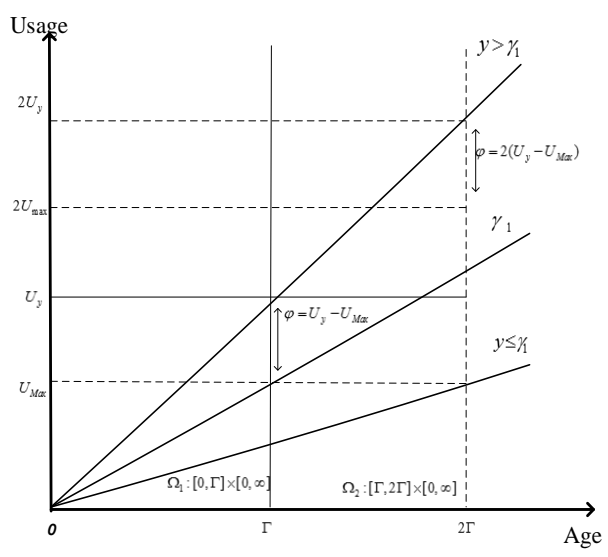

Fig. 1. A lease contract with $m$ periods $(m \Gamma, m=2)$ and the maximum usage $\left(U_{\max }\right)$

$$
\Psi\left[k, \delta_{y}\right]=\sum_{i=1}^{m} \Pi_{i}\left[k, \delta_{y}\right] ; \Pi_{i}\left[k, \delta_{y}\right]=J^{1}\left(k, \delta_{y}\right)+J^{2}\left(k, \delta_{y}\right)
$$

Preventive maintenance cost:

Let $C_{p m}\left(\delta_{y}\right)$ and $C_{r}$ be the cost of the j-th PM and the cost of each minimal repair. If $C_{p m}\left(\delta_{y}\right)=C_{0}+C_{v} \delta_{y}$ then the expected total PM cost over the LC period $(0, m \Gamma], m=1,2, \ldots$ is given by

$$
J^{1}\left(k_{y}, \delta_{y}\right)=\sum_{j=1}^{k} C_{p m}\left(\delta_{y}\right)=k C_{0}+C_{v} \sum_{j=1}^{k} \delta_{y}
$$

Corrective maintenance cost:

If $C_{r}$ is the cost of each minimal repair, then

$$
J^{2}\left(k, \tau_{y}, \delta_{y}\right)=C_{r}\left(R_{y}(\Gamma)-\sum_{j=1}^{k}\left(\Gamma-j \tau_{y}\right) \delta_{y}\right)
$$

After simplification for $m=1$, we have the expected total cost of the lessor given by

$$
\Psi\left[k, \delta_{y}\right]=C_{r} R_{y}(\Gamma)-\left\{C_{r} \sum_{j=1}^{k}\left[\left(\Gamma-C_{v} / C_{r}\right)-j \tau_{y}\right] \delta_{y}-k C_{0}\right\}
$$

Expected total revenue:

The expected total revenue is the sum of the price of LC and some additional revenues due to the total usage of the equipment is greater than $U_{\max }$ (the maximum usage). The price of LC is dependent on the usage rate and the number of LC periods (m) given by

$$
P(m)=P\left\{e^{-\varphi m} / e^{-\varphi}\right\}=P\left\{e^{-\varphi(m-1)}\right\}
$$

where $0 \leq \varphi<1$ represents a discount parameter. This price function gives a discount price when $m \geq 2$. The additional revenues earned by the lessor is given by

$$
\Phi(m, y)=C_{d} \sum_{j=1}^{m} \operatorname{Max}\left\{0,\left(y \times j \Gamma-j U_{\max }\right)\right\}
$$


where $C_{d}$ is the additional cost charged (e.g. $\$ / \mathrm{km}$ or $\$ /$ page copied). $\Phi(m, y)$ is viewed as some additional revenues for the lessor. As a result, the expected profit is given by

$$
E\left[\pi_{y}\right]=P(m)+\Phi(m, y)-\Psi\left[k_{y}, \delta_{y}\right]-m C_{b}^{r}
$$

where $C_{b}^{r}$ is the annual cost of the remanufactured equipment.

\subsection{Lessee's Expected Profit}

The lessee's expected profit is equal to the expected total revenue minus the total expected cost, that will be given as follows.

$$
E\left[\phi_{y}\right]=K(m \Gamma)-P(m)-\Phi(m, y)
$$

\section{Optimization}

Case 1: [Joint Optimization]

We consider that the lessee and lessor would like to work jointly to obtain a joint optimal profit. Then, the strategy set of the lessor and the lessee is given by $Q_{y}=\left\{\left(\delta_{y}, \tau_{y}, k_{y}, P, m\right) \mid 0 \leq \delta_{y} \leq 1, \tau_{y} \geq 0, k_{y} \geq 0\right\}$. Here the decision variables for the lessor are $\delta_{y}, \tau_{y}, k_{y}, P$, and $m$ is for the lessee. Both players choose the set of strategies $\quad q_{y}^{*} \in Q_{y} \quad$ that $\quad$ solves $\quad \max _{q} E\left[\Pi_{y}\right]=\max _{q}\left\{E\left[\phi_{y}\right]+E\left[\pi_{y}\right]\right\}$ where $E\left[\phi_{y}\right]$ and $E\left[\pi_{y}\right]$ are the total expected profit for the lessee and lessor. The coordination solution is obtained by solving the following problem.

$$
\max _{\delta_{y}, \tau_{y}, k_{y}} E\left[\Pi_{y}\right]=\max _{q}\left\{E\left[\phi_{y}\right]+E\left[\pi_{y}\right]\right\} \text {, s.t. } \delta_{y}, \tau_{y}, P>0 \text {, and } k_{y}, m>O \text { (integer) }
$$

\section{Case 2: [Non Cooperative Nash Game Theory]}

Next, we consider a win-win decision situation for the lessee and lessor, and model using a Nash game theory formulation. In this scheme, the strategy set of the lessee and lessor are $Q_{y}^{\text {nash }}=\left\{\left(\delta_{y}, \tau_{y}, k_{y}, P, m\right) \mid 0 \leq \delta_{y} \leq 1, \tau_{y} \geq 0, k_{y} \geq 0\right\}$. If $E\left[\phi_{y}\right]$ and $E\left[\pi_{y}\right]$ are the total expected profit for the lessee and lessor, both players choose the set of strategies $q_{y}^{*} \in Q_{y}^{\text {nash }}$ that solves $\max _{q} E\left[\phi_{y}\right]=\max _{q} E\left[\pi_{y}\right]$ with the optimal values of the set of strategies $q_{y}^{*} \in Q_{y}^{\text {nash }}$ for the lessee and lessor by solving the following problem.

$$
\max _{\delta_{y}, \tau_{y}, k_{y}} E\left[\phi_{y}\right]=\max _{\delta_{y}, \tau_{y}, k_{y}} E\left[\pi_{y}\right] \text {, s.t. } \quad \delta_{y}>0, \tau_{y}>0, k_{y}>0 \text { and integer }
$$

\section{$5 \quad$ Numerical Example}

The parameter values used are: $R=0.4, \beta=1.5, \Gamma=12$ (months), $U=24\left(1 \times 10^{4} \mathrm{Km}\right)$, $(\gamma=U / \Gamma=1), y_{0}=1, \rho=2$ and $C_{v}=0.5 C_{m}, C_{a}=0.75 C_{r}, \zeta=12$ (units) . 
Table 1. Results for case 1 and case 2 with $\mathrm{LC}$ region 12 months $(\mathrm{m}=1)$

\begin{tabular}{cccccccc}
\hline & \multicolumn{3}{c}{ Case 1: Joint Optimization } & \multicolumn{4}{c}{ Case 2: Non- Cooperative Nash Game } \\
Theory
\end{tabular}

Table 1 shows optimal solutions for cases 1 and 2 . In Case 1, as the usage rate increases, the profit gained for the lessor [lessee] increases [decreases], and the profit for the lessee is less than that of lessor started at $\mathrm{y}=3.0$ (as the additional cost charged to the customer is much bigger as $\mathrm{y}$ is larger $(\mathrm{y}>2.5))$. In contrast, the profit resulting from the Nash bargaining solution (Case 2) is always the same for both the lessor and the lessee for each y, and it decreases as y increases. This is due to the total profit generated by both parties decreasing as y increases (or more failures occur and hence bigger downtimes as the usage is larger). The joint optimization is favor the lessor. This is expected as the bargaining strategy shares equally the total profit generated.

\section{Managerial implementation}

The results shows that implementation of the leasing concept connected to a product remanufactured can undoubtedly deliver economic benefits to the lessor and lessee. As it is not a new product, and hence a thorough preparation of a special marketing strategy that results in a customer acceptance is required. This is agreed with [3].

\section{Conclusion}

In this paper we have studied a usage based lease contract for remanufactured equipment such as dump trucks. Under this lease contract, the equipment is leased for a period of $\Gamma$ and a maximum usage, $U$. We find the optimal solution jointly (joint optimization) for both parties, and then seek the optimal decisions using a Nash game theory formulation. One can model the decision problems for the lessor and the lessee using a Stackelberg game theory formulation, and consider a subsequent of LC periods in which the usage pattern may change significantly from period to period (this is due to a different lessee leases the equipment). These two topics are currently under investigation.

\section{Acknowledgements}

This work is funded by the Ministry of Research, Technology, and Higher Education of the Republic of Indonesia through the scheme of "PUPT 2018" with contract number SP DIPA-042.06.1.401516/ 2018. 


\section{References}

1. Neely, A.: Exploring the financial consequences of the servitization of manufacturing, Operations Management Research 1(2), 103-118 (2008).

2. Kindström D. and Kowalkowski C.: Service innovation in product centric firms: A multidimensional business model perspective. Journal of Business and Industrial Marketing, 29(2), 96-111 (2014).

3. Mont, O., Dalhammar, C., Jacobsson, N.: A new business model for baby prams based on leasing and product remanufacturing. Journal of Cleaner Production 14(17), 1509-1518 (2006).

4. Besch, K.: Product-service systems for office furniture: Barriers and opportunities on the European market. Journal of Cleaner Production 13(10-11), 1083-1094 (2005).

5. Lindahl, M., Sundin, E., Sakao, T.: Environmental and economic benefits of Integrated Product Service Offerings quantified with real business cases. Journal of Cleaner Production 64, 288-296 (2014).

6. Yalabik, B., Chhajed, D., Petruzzi, N.C.: Product and sales contract design in remanufacturing. International Journal of Production Economics 154, 299-312 (2014).

7. Lieckens, K.T., Colen, P.J., Lambrecht, M.R.: Network and contract optimization for maintenance services with remanufacturing. Computers and Operations Research 54, 232 $244(2015)$.

8. Jaturonnatee J, Murthy D N P, and Boondiskulchok R .: Optimal preventive maintenance of leased equipment with corrective minimal repairs. European Journal of Operational Research 174, 201-215 (2006).

9. Murthy D N P and Jack N.: Extended warranties, maintenance service and lease contracts. Springer Series in Reliability Engineering, London (2014.).

10. Bhaskaran, Sreekumar R and Gilbert S.: Implications of channel structure for leasing or selling durable goods. McCombs Research Paper Series No. IROM-01-07 (2007).

11. Pongpech J and Murthy D N P.:Optimal periodic preventive maintenance policy for leased equipment. Reliability Engineering \& System Safety 91, $772-777$ (2006).

12. Pongpech J, Murthy D N P and Boondiskulchok R.: Maintenance strategies for used equipment under lease. J. Qual Maintenance Eng 12, 52-67 (2006).

13. Yeh R H, Kao K C and Chang W I .: Preventive maintenance policy for leased products under various maintenance costs. Expert Systems with Applications 38(4), 3558-3562 (2011).

14. Aras F, Gullu R and Yurulmez S.: Optimal inventory and pricing policies for remanufacturable leased products. Int. J . Production Economics 133, 262-271 (2011).

15. Hamidi M, Liao H and Szidarovszky F.: Non-cooperative and cooperative game-theoretic models for usage-based lease contracts,. European Journal of Operational Research 255, 163-174 (2016).

16. Iskandar B P and Husniah $\mathrm{H}$.: Optimal preventive maintenance for a two dimensional lease contract. Computers \& Industrial Engineering 113 , 693-703 (2017).

17. Yeh R H, Kao K C and Chang W I.: Optimal maintenance policy for leased equipment using failure rate reduction. Computers \& Industrial Engineering 57(1), 304-309 (2009). 